\title{
Addressing the interaction between food insecurity, depression risk and informal work: findings of a cross-sectional survey among informal women workers with young children in South Africa
}

Christiane Horwood $^{1 *} \mathbb{0}$, Lyn Haskins ${ }^{1}$, Rachael Hinton ${ }^{2}$, Catherine Connolly ${ }^{1}$, Silondile Luthuli ${ }^{1}$ and Nigel Rollins ${ }^{3}$

\begin{abstract}
Background: There is a high burden of depression globally, including in South Africa. Maternal depression is associated with poverty, unstable income, food insecurity, and lack of partner support, and may lead to poor outcomes for mothers and children. In South Africa one-third of working women are in informal work, which is associated with socioeconomic vulnerability.

Methods: A cross sectional survey explored work setting and conditions, food security and risk of depression among informal working women with young children (0-3 years). Depression risk was assessed using the Edinburgh Postnatal Depression Score (EPDS) and Whooley score. Food insecurity was evaluated using Household Food Insecurity Access Scale. Data was analysed using SPSS and Stata.

Results: Interviews were conducted with 265 informal women workers. Types of work included domestic work, home-based work, informal employees and own account workers, most of whom were informal traders. Most participants (149/265; 56.2\%) earned between US\$70-200 per month, but some participants $(79 / 265 ; 29.8 \%)$ earned $<$ US\$70 per month, and few earned > US\$200 per month (37/265; 14.0\%). Many participants experienced mild $(38 / 267 ; 14.3 \%)$, moderate $(72 / 265 ; 27.2 \%)$ or severe $(43 / 265 ; 16 \%)$ food insecurity. Severe food insecurity was significantly higher among participants with the lowest income compared to those with the highest income $(p=0.027)$. Women who received financial support from the baby's father were less likely to be food insecure $(p=0.03)$. Using EPDS scores, 22/265 (8.3\%) women were designated as being at risk of depression. This was similar among postnatal women and women with older children. Household food insecurity was significantly associated with depression risk $(p<0.001)$.
\end{abstract}

Conclusions: Informal women workers were shown to be vulnerable with low incomes and high rates of food insecurity, thus increasing the risk for poor maternal health. However, levels of depression risk were low compared to

\footnotetext{
*Correspondence: horwoodc@ukzn.ac.za

${ }^{1}$ Centre for Rural Health, George Campbell Building, Howard College

Campus, University of KwaZulu-Natal, Durban, South Africa
}

Full list of author information is available at the end of the article give appropriate credit to the original author(s) and the source, provide a link to the Creative Commons licence, and indicate if changes were made. The images or other third party material in this article are included in the article's Creative Commons licence, unless indicated otherwise in a credit line to the material. If material is not included in the article's Creative Commons licence and your intended use is not permitted by statutory regulation or exceeds the permitted use, you will need to obtain permission directly from the copyright holder. To view a copy of this licence, visit http://creativecommons.org/licenses/by/4.0/. The Creative Commons Public Domain Dedication waiver (http://creativecommons.org/publicdomain/zero/1.0/) applies to the data made available in this article, unless otherwise stated in a credit line to the data. 
previous estimates in South Africa, suggesting that informal workers may have high levels of resilience. Interventions to improve social protection, access to health services, and support for safe childcare in the workplace could improve the health and wellbeing of these mothers and support them to care for their children.

Keywords: Working women, Informal economy, Antenatal depression, Postnatal depression, Food insecurity, Maternal health, Child health, South Africa, Africa

\section{Background}

Depression represents a huge burden of disease globally, particularly among women during pregnancy and in the post-partum period [1]. Depression in pregnancy and after childbirth is highly prevalent in low-income countries, especially in high poverty settings [2-4]. In South Africa (SA) estimated rates of depression in the antenatal period range from 22 to 47\% [5-7], and several studies suggest that about one-third of postnatal women are at high risk of depression [8-11]. Depression contributes heavily to the overall disease burden in SA [12], and recent evidence suggests that perinatal anxiety disorders are also prevalent [13].

Depression is associated with significant life challenges, including poverty, unstable income, food insecurity, lack of partner support, violence and poor health $[9,10,14-$ 17]. Maternal depression reduces quality of life and is a leading cause of disability and poor maternal health outcomes, especially in the context of HIV $[11,18]$. Further, maternal depression has been associated with adverse effects on the quality of the mother-infant relationship and child development outcomes [4, 19], which can have implications for young children's long-term psychosocial, cognitive, and economic well-being [10, 11]. Maternal mental health is therefore an important public health concern in SA, however it is frequently neglected and continues to be of low priority in health care practices $[3,7]$.

Food insecurity is defined as having uncertain or limited availability of nutritionally appropriate food or being unable to procure food in socially acceptable ways [20, 21]. Depression and food insecurity frequently occur together. Food insecurity has been shown to be strongly associated with depression [22], and depression in mothers in low-income households may be a predictor of household food insecurity [23]. Household food insecurity is associated with poor health, development and behavioural outcomes among children [24, 25], and is common in SA, with around $25 \%$ of the population considered food insecure [26].

Informal work is frequently associated with vulnerability and poverty, particularly financial and food insecurity [27, 28]. Of the 6.8 million working women in SA, almost 2 million work informally, the largest groups being informal traders, agricultural workers and workers in private homes (domestic workers) [29]. By definition, informal workers do not have access to income protection including unemployment, sickness and maternity benefits. The period during pregnancy and after childbirth is a vulnerable time for all mothers since childcare and household responsibilities often fall disproportionately on women [29]. In SA, femaleheaded households are common (43\%) [30], and it may be especially difficult for mothers in informal work, often already vulnerable due to their working conditions and reduced earning potential, to manage ongoing childcare and household responsibilities [30]. Several studies have shown how poverty and food insecurity interact in a vicious cycle among socially and economically deprived populations, leading to depression and poor health outcomes among women $[9,15]$.

Thus, factors associated with food insecurity and depression are likely experienced by women working in the informal economy. However, little focus has been given to the multiple risks of depression facing female informal workers and data is sparse among this population group, especially in low- and middle-income settings [16]. Data from one Brazilian study suggests a higher risk of psychological symptoms among women informal workers compared to formal workers living in the same neighbourhood [31].

Women who work in the informal economy in SA as a group are particularly neglected in maternal and child health programmes, and there have been no attempts to address their particular needs [32]. For example, informal workers face barriers that may prevent their seeking antenatal, immunisation or reproductive health care services, but no provision is made for them to attend outside of working hours or be fast-tracked so they can return to work. To address this gap, we conducted this study to explore the interaction between informal work, food insecurity and depression among women with young children working in the informal economy in urban and peri-urban areas of Durban, KwaZulu-Natal (KZN) Province, SA.

\section{Methods}

A cross sectional survey methodology was employed to explore the work setting and conditions, income, food security and risk of depression among informal working women with children under the age of 3 years. 


\section{Study setting}

The study was conducted in three primary health care (PHC) clinics in three townships in Durban, South Africa. In these areas unemployment is high at around $20 \%$, with high rates of poverty, and an average annual income of R29 400 (USD2000) [33]. In addition, there is poor access to basic services including water and sanitation and informal housing is common, but most households do have access to electricity [34]. A recent study in Durban found that women in the informal economy work long hours and many only earn $<$ R1000 (USD70) per month [27]. Primary caregivers of children living in a low-income household are entitled to an SA government provided Child Support Grant (CSG) of R420 (USD30) per month for each child [35].

Health care for pregnant women and children is provided free of charge in PHC clinics, and there are high rates of antenatal clinic attendance (94\%) and facility-based delivery (96\%) [36]. HIV prevalence is high among young women in $\mathrm{KZN}$, with $41.1 \%$ of pregnant women attending government antenatal clinics testing HIV positive in 2017 [37].

\section{Recruitment and sampling}

Women were recruited while waiting in the queue in the three participating clinics. Trained fieldworkers approached women in the clinic waiting area and explained the study. Eligibility was determined using a structured screening tool based on the definition of informal work set out above (Additional file 1). Eligible participants were informal workers, aged 18 years or older, with a child under the age of 3 years. Informal workers were either informally employed or own account (self-employed) workers. Informally employed women were defined by: (1) receiving money from an employer; (2) having no formal work contract; and (3) not contributing to SA's mandatory Unemployment Insurance Fund (UIF). Own-account workers provided goods and services directly to customers but were not tax registered or paying tax. Women were excluded from the study if they worked fewer than 3 days per week or had been in informal work for $<6$ months in order to focus on those women with longer term experience of informal work.

A stratified sampling approach was employed to recruit equal numbers of eligible women with children aged $<1$ year (defined as the postnatal period) and mothers of children aged 12-35 months. Given the well-documented high risk of postnatal depression in SA, this approach was used to determine depression prevalence in the postnatal population compared to the wider population of informally working mothers.
A sample size of 192 women (96 with children aged $<1$ year and 96 with children aged 12-35 months) was required to detect a $20 \%$ difference in depression risk among postnatal women compared to the general population of informal working mothers. This sample size calculation assumes a $35 \%$ rate of depression risk in women with children $1-<3$ years of age with $95 \%$ probability and $80 \%$ power.

\section{Data collection}

Data collection was undertaken among women waiting in the queue in the three participating clinics. Trained fieldworkers approached women in the clinic waiting area and explained the study. Eligibility was determined using a structured screening tool based on the definition of informal work set out above. Data were collected using a structured questionnaire administered in the local language (IsiZulu) (Additional file 1), and data collection continued until the sample size was reached. All eligible women agreed to participate and the survey was conducted in a separate room in the clinic to ensure privacy.

We recorded the type of work based on the mother's reported occupation, workplace (home/street/employer's premises) and working conditions (own account/selfemployed/unpaid or paid in kind).

Risk of depression was assessed using two tools validated for use in SA and translated into IsiZulu: the Edinburgh Postnatal Depression Scale (EPDS) [38, 39] and the Whooley score [6]. The EPDS is the most widely used screening tool for depression among postnatal women, and has been widely used and validated in many settings including in South Africa [40], including among populations of non-postnatal women [41] and in high HIV prevalence settings [42]. The EPDS employs a 7 day recall of depressive symptoms including anxiety, tearfulness and poor sleep. A cut-off score of $\geq 13$ was used. Although a range of cut-off scores have been used in different settings, this cut-off has been most commonly used in South Africa $[3,6,9,10,39,43]$. The Whooley questions are three questions to assess low mood and lack of interest as well as suicidal ideation. These two tools were used together to allow triangulation of the findings from two screening tools for depression risk.

The USAID Household Food Insecurity Access Scale (HFIAS), adapted and translated to IsiZulu, was used to assess food insecurity. The HFIAS tool is a nine-item experience-based measure with questions about experiences of food insecurity of the past 4 weeks. The tool is designed to be easy to use and applicable to diverse sociocultural settings, and examines food security related to three domains: anxiety about food access; insufficient quality of food; and insufficient quantity of food [44]. The HFIAS can been shown to be broadly 
applicable across different cultural contexts and has been widely used and validated in Africa, including in South Africa [9, 22, 45]

A professional psychologist, who was IsiZulu-speaking and had experience with both the EPDS and Whooley tools, trained the fieldworkers to assess depression risk using the two tools. The psychologist also supervised data collection to ensure the correct administration of the tools in the field.

\section{Data analysis}

Quantitative analysis was undertaken using SPSS version 24 and Stata V15.1. Background characteristics, feeding and childcare practices, and conditions of informal work are presented as frequencies and proportions.

To describe the types of work undertaken, participants were retrospectively categorised using a series of steps. Firstly, all women who reported they worked from home were categorised as home-based workers. Women were categorised as domestic workers if they reported they worked in a private household undertaking domestic or childcare work. All other women were categorised either as employees if they reported receiving a wage from an employer, or as own account workers if they were self-employed. Sub-categories of own account workers included informal traders and a variety of other own account jobs.

For the EPDS high risk of depression was determined by a score of $\geq 13$. Two positive answers were considered a positive score for the Whooley questions. For both tools a positive answer to questions about suicidal ideation was considered high depression risk, regardless of the answers to the other questions.

Household food security was scored on a scale of $0-27$, where 27 is the most food insecure, using the established and validated scoring for this tool [46]. For the multivariable analysis the food insecurity index was dichotomised into food secure (none or mild food insecurity) and food insecure (moderate or severe food insecurity), and the EPDS depression score was analysed on a continuous scale and means and standard deviations reported. The analysis was a two-step process. Initially a multi variable logistic model was used to identify factors associated with food insecurity. Due to the over dispersion of the EPDS depression score, a multi-variable negative binomial model including food insecurity was used to identify factors associated with PND score. In both cases only factors significant at $p<0.3$ in bivariate analysis were included in the multi-variable model. Adjusted and unadjusted odds ratios and 95\% confidence limits are reported. Stata V15.1 statistical software was used in the analysis

\section{Ethical considerations}

All participating women provided written informed consent. Screening, consent processes and data collection were conducted in a private area in the PHC clinics. Referral procedures were established with staff at each of the PHC clinics to offer additional clinical and social support to participants as required. All women identified as at risk of depression or with any thoughts of selfharm were immediately referred to clinic staff for further assessment. Follow up support from a study counsellor was offered to all women identified as being at risk of depression. Women identified as having moderate or severe food insecurity were referred to a clinic-based social worker.

\section{Results}

A total of 265 interviews were conducted with mothers in informal work between December 2018 and March 2019. Just over $50 \%$ of participants had completed secondary school and nearly half were in a relationship but not living with their partner. Close to $50 \%$ of participants reported themselves HIV positive. Characteristics of participating mothers are shown in Table 1.

\section{Infant feeding and childcare}

Due to the stratified sampling design there were similar numbers of participants with children aged $<12$ months of age and with children aged between 12-35 months.

\section{Table 1 Characteristics of participating mothers}

\begin{tabular}{ll}
\hline Characteristics of participants & $\begin{array}{l}\text { All participants } \\
\mathbf{N}=\mathbf{2 6 5}(\%)\end{array}$ \\
\hline $\begin{array}{l}\text { Median age } \\
\text { Population group (Black / African) }\end{array}$ & 29 years (IQR 25-34 years) \\
Education & \\
No schooling & $2(0.8)$ \\
Primary school Grade 1-7 & $7(2.6)$ \\
Secondary school Grade 8-11 & $122(46.0)$ \\
Completed school (Grade 12) & $134(50.6)$ \\
Most recent relationship status & \\
Single & $52(19.6)$ \\
Married & $22(8.3)$ \\
Separated/divorced/widowed & $4(1.5)$ \\
In a relationship, living with partner & $61(23.0)$ \\
In a relationship, not living with partner & $126(47.5)$ \\
Mother is currently in a relationship with the & $208(78.5)$ \\
child's father & \\
Has another child aged <3 years & $19(7.2)$ \\
HIV status & \\
Mothers reported having had an HIV test & $256(96.6)$ \\
Mother reported herself HIV positive & $131(49.4)$
\end{tabular}


Most mothers had breastfed their child, however, only $60 \%$ of infants $<12$ months of age were still breastfeeding. Most mothers $(171 / 265 ; 64.5 \%)$ took time off work following childbirth and were financially supported during this time by the baby's father $(109 / 265 ; 41.1 \%)$, other family members $(72 / 265 ; 27.2 \%)$, the SA CSG $(71 / 265$ : $26.8 \%)$, and their own savings (21/265; 7.9\%).

The duration of leave taken at the time of childbirth was short, with around $60 \%$ of mothers returning to work by the time the baby was 3 months old. Over one-third of mothers did not take any time off work (Table 2).

\section{Conditions of informal work}

Over $40 \%$ of participants had been at the same job between 1 and 3 years, and close to half worked 5-6 days each week. Three-quarters of women reported they worked regular hours, however over $60 \%$ did not benefit from a fixed income and were paid depending on the work done. An overview of informal working conditions reported by participants is shown in Table 3 .

\section{Types of informal work}

Just over $40 \%$ of participants reported they worked as employees in informal enterprises, including as cleaners (19), hairdressers (18), waiters (7), shop assistants (24), factory workers (12), office administrators (4), call centre workers (3), and security guards (3). Home based work included hairdressing (23), and making and selling goods, such as crafts, sewing, and baking (9). Other participants were self-employed as informal traders and in a variety of other own account jobs such as crèche work, fashion design, catering, plumbing, welding, sewing and marketing (Table 4).

A comparison of the characteristics of the different categories of informal work are shown in Table 4. Homebased workers were most likely to work 7 days per week and not receive a fixed wage. Employed women and domestic workers benefited from more regular hours compared with other informal workers, however, many still could not rely on a fixed wage.

\section{Income among informal workers}

Most participants $(149 / 265$; 56.2\%) reported earning between R1 000-3 000 (USD70-USD200) per month for their work. However, many women $(79 / 265 ; 29.8 \%)$ earned < R1 000 (USD70) per month, with the highest proportion being home-based workers. A minority of women earned more than R3000 (> USD200) per month (37/265; 14.0\%).

Most participants received additional income from the CSG (208/265; 78.5\%), either for one (89; 33.6\%), two (74; $27.9 \%)$, three (32; $12.1 \%)$, or more $(13 ; 7.8 \%)$ children. In most cases participants reported that the father of their
Table 2 Duration of breastfeeding, duration of postnatal leave and childcare practices during work hours

\begin{tabular}{|c|c|c|c|}
\hline Characteristics & $\begin{array}{l}<12 \text { months } \\
n=132(\%)\end{array}$ & $\begin{array}{l}12-35 \text { months } \\
n=133(\%)\end{array}$ & $\begin{array}{l}\text { All } \\
n=265(\%)\end{array}$ \\
\hline \multicolumn{4}{|c|}{ Baby's age when mother stopped breastfeeding } \\
\hline Never breastfed & $18(13.6)$ & $27(20.3 \%)$ & $45(17.0 \%)$ \\
\hline Still breastfeeding & $80(60.6)$ & $15(11.3)$ & $95(35.8 \%)$ \\
\hline 0 to $<3$ months & $15(11.4)$ & $15(11.3)$ & $30(11.3)$ \\
\hline 3 to $<6$ months & $11(8.3)$ & $14(10.5)$ & $25(9.4)$ \\
\hline 6 to $<9$ months & $8(6.1)$ & $17(12.8)$ & $25(9.4)$ \\
\hline 9 to $<12$ months & & $7(5.3)$ & $7(5.3)$ \\
\hline 12 to $<15$ months & & $17(12.8)$ & $17(12.8)$ \\
\hline 15 to $<18$ months & & $5(3.8)$ & $5(3.8)$ \\
\hline 18 to 24 months & & $9(6.8)$ & $9(6.8)$ \\
\hline$>24$ months & & $7(5.3)$ & $7(5.3)$ \\
\hline \multicolumn{4}{|c|}{ Baby's age when mother returned to work } \\
\hline $\begin{array}{l}\text { Did not take time off } \\
\text { work }\end{array}$ & $40(30.3)$ & $54(40.6)$ & $94(35.5)$ \\
\hline$<3$ months & $43(32.6)$ & $22(16.5)$ & $65(24.5)$ \\
\hline 3 to $<6$ months & $29(22.0)$ & $36(27.1)$ & $65(24.5)$ \\
\hline 6 to $<9$ months & $4(3.0)$ & $15(11.3)$ & $19(7.2)$ \\
\hline 9 to $<12$ months & 0 & 0 & 0 \\
\hline 12 to $<15$ months & & $1(0.8)$ & $1(0.4)$ \\
\hline 15 to $<18$ months & & $1(0.8)$ & $1(0.4)$ \\
\hline 18 to $<24$ months & & 0 & 0 \\
\hline$>24$ months & & $2(1.5)$ & $2(0.8)$ \\
\hline $\begin{array}{l}\text { Not yet returned to } \\
\text { work }\end{array}$ & $6(4.5 \%)$ & & $6(2.3)$ \\
\hline $\begin{array}{l}\text { Missing /mother } \\
\text { unsure }\end{array}$ & $10(7.6)$ & $2(1.5)$ & $11(4.5)$ \\
\hline $\begin{array}{l}\text { Took baby to work } \\
\text { initially }\end{array}$ & $26(19.7)$ & $28(21.1)$ & $54(20.4 \%)$ \\
\hline \multicolumn{4}{|c|}{ Person who usually cares for child while mother is working } \\
\hline Child's grandmother & $31(23.5)$ & $21(15.8)$ & $52(19.6 \%)$ \\
\hline Child's father & $2(1.5)$ & $1(0.8)$ & $3(1.1 \%)$ \\
\hline Child's sibling & $1(0.8)$ & $2(1.5)$ & $3(1.1 \%)$ \\
\hline Other relative & $28(21.2)$ & $18(13.5)$ & $46(17.4 \%)$ \\
\hline Non-relative & $44(33.3)$ & $69(51.9)$ & $113(42.6 \%)$ \\
\hline $\begin{array}{l}\text { Mother herself (takes } \\
\text { child to work or } \\
\text { works from home) }\end{array}$ & $26(19.7)$ & $18(13.5)$ & $44(16.6 \%)$ \\
\hline \multicolumn{4}{|c|}{ Place where child is cared for during working hours } \\
\hline Mother's residence & $76(57.6)$ & $47(35.3)$ & $123(46.4 \%)$ \\
\hline Carer's home & $22(16.7)$ & $20(15.0)$ & $42(15.8 \%)$ \\
\hline Current workplace & $3(2.3)$ & $2(1.5)$ & $5(1.9 \%)$ \\
\hline Crèche or school & $29(22.0)$ & $62(46.6)$ & $91(34.3 \%)$ \\
\hline Other & $2(1.5)$ & $2(1.5)$ & $4(1.5)$ \\
\hline
\end{tabular}

child was working $(194 / 265 ; 73.2 \%)$ and had provided either money or material items for the baby in the past one month $(181 / 265 ; 68.7 \%)$.

Most participants reported having a bank account $(178 / 265 ; 67.2 \%)$. Despite being low paid, many mothers 


\begin{tabular}{|c|c|}
\hline Conditions of informal work & $\begin{array}{l}\text { All workers } \\
n=265(\%)\end{array}$ \\
\hline \multicolumn{2}{|l|}{ Length of time in the same job } \\
\hline Less than 1 year & $93(35.1 \%)$ \\
\hline $1-3$ years & $114(43.0 \%)$ \\
\hline 4 or more years & $58(21.9 \%)$ \\
\hline \multicolumn{2}{|l|}{ Number of days worked per week } \\
\hline $3-4$ days & $94(35.5 \%)$ \\
\hline $5-6$ days & $119(44.9 \%)$ \\
\hline 7 days & $52(19.6 \%)$ \\
\hline Works in same location every day & $208(78.5 \%)$ \\
\hline Regular hours of work & $201(75.8 \%)$ \\
\hline \multicolumn{2}{|l|}{ Work setting } \\
\hline Mostly indoors & $220(83.0 \%)$ \\
\hline Mostly outdoors with shelter & $22(8.3 \%)$ \\
\hline Mostly outdoors without shelter & $23(8.7 \%)$ \\
\hline \multicolumn{2}{|l|}{ Wage is fixed or variable } \\
\hline Receives a fixed wage & $101(38.1 \%)$ \\
\hline Not fixed / depends on work done & $164(61.9 \%)$ \\
\hline \multicolumn{2}{|l|}{ How often receives wages } \\
\hline Weekly & $42(15.8 \%)$ \\
\hline Monthly & $176(66.4 \%)$ \\
\hline Irregularly & $40(15.1 \%)$ \\
\hline Other & $7(2.6 \%)$ \\
\hline
\end{tabular}

were saving money monthly $(128 / 265$; $48.3 \%)$, had a savings plan $(123 / 265 ; 46.4 \%)$ and paid towards a funeral insurance policy $(110 / 265 ; 41.5 \%)$.

\section{Financial responsibilities}

Participants were asked about current financial outgoings for themselves, their child and the household. Most expenses for which the mother was responsible were shared with others (Table 5). Expenses related to the child were frequently shared with the child's father. Over half of participants reported they did not contribute to household bills or that these costs were shared with other family members. However, most participants reported being responsible for their personal expenses such their own clothing $(122 / 265 ; 46.0 \%)$, toiletries and/or cosmetics $(73 / 265 ; 27.5 \%)$ and paying for their cell phone or airtime $(21 / 265 ; 7.9 \%)$. Some participants reported they regularly financially supported other family members $(25 / 265$; $9.4 \%)$ including their parents, siblings or other children not living with them.

\section{Household food insecurity}

A household is considered to be food secure if household members can access sufficient, safe and nutritious foods of their choice without anxiety. Most women had experienced some form of household food insecurity in the last month, and less than half were designated as food secure $(112 / 265 ; 42.3 \%)$. Some participants experienced mild food insecurity $(38 / 267 ; 14.3 \%)$ where they could maintain the quantity of the household food, but the food was less diverse and not their preferred choice. Nearly $30 \%$ of participants had moderate food insecurity (72/265; $27.2 \%)$ where not only was the food was of lower quality, but sometimes the quantity of food had to be reduced by limiting either the number or the size of meals. Further, $16 \%(43 / 265)$ of participants had severe food insecurity where they often had to reduce the number or size of meals, or had run out of food, gone to bed hungry, or spent an entire day and night without food.

Severe household food insecurity decreased with increasing income: $19 / 79$ (24.0\%) participants with an income $<$ R1 000 were severely food insecure, compared to $22 / 149(14.8 \%)$ of participants with an income of R1 000-3 000 and 2/37 (5.4\%) participants with an income over R3 000. There was a significant higher prevalence of severe food insecurity among the lowest paid compared to the highest $(p=0.027)$.

In multivariable analysis, moderate or severe food insecurity was higher among mothers with an income

Table 4 Working conditions in different types of informal work

\begin{tabular}{|c|c|c|c|c|c|c|}
\hline \multirow[t]{2}{*}{ Type of work } & \multicolumn{6}{|c|}{ Conditions of work $(\mathrm{N}=265)$} \\
\hline & $\begin{array}{l}\text { Proportion } \\
\text { in each } \\
\text { category } \\
\mathrm{n}(\%)\end{array}$ & $\begin{array}{l}\text { Earning }<\text { R } 1000 \\
\text { monthly } \\
\mathrm{n}(\%)\end{array}$ & $\begin{array}{l}\text { Irregular } \\
\text { working } \\
\text { hours } \\
\mathrm{n}(\%)\end{array}$ & $\begin{array}{l}\text { Work } 7 \text { days per week } \\
\text { n (\%) }\end{array}$ & $\begin{array}{l}\text { Paid monthly } \\
\text { n (\%) }\end{array}$ & $\begin{array}{l}\text { Fixed wage } \\
\text { n (\%) }\end{array}$ \\
\hline Domestic workers & $56(21.1)$ & $12 / 56(21.4)$ & $5 / 56(8.9)$ & $1 / 56(1.8)$ & $49 / 56(87.5)$ & $36 / 56(64.3)$ \\
\hline Home based workers & $49(18.5 \%)$ & $25 / 49(51.0)$ & $29 / 49(59.2)$ & $28 / 49(57.1)$ & $19 / 49(37.8)$ & $1 / 49(2.0)$ \\
\hline Employed in informal business & $116(43.8)$ & $31 / 116(26.7)$ & 20/116 (17.2) & $10 / 116(8.6)$ & $84 / 116(72.4)$ & $60 / 116(51.7)$ \\
\hline Own account workers: Informal traders & $29(10.9)$ & $10 / 29(34.5)$ & $6 / 29(20.7)$ & $10 / 29(34.5)$ & $16 / 29(55.2)$ & $3 / 29(10.3)$ \\
\hline Own account workers: other & $15(5.7)$ & $1 / 15(6.7)$ & 4/15 (26.6) & $3 / 15(20.0)$ & 8/15 (53.3) & $1 / 15(6.7)$ \\
\hline
\end{tabular}


Table 5 Financial responsibilities of participants

\begin{tabular}{|c|c|}
\hline Participants' financial responsibilities & $\begin{array}{l}\text { All } \\
n=265(\%)\end{array}$ \\
\hline \multicolumn{2}{|l|}{ Household expenses } \\
\hline \multicolumn{2}{|c|}{ Responsible for paying water, electricity, rates, monthly costs } \\
\hline Mother alone & $62(23.4 \%)$ \\
\hline Shares the cost & $62(23.4 \%)$ \\
\hline Do not pay/not applicable & $141(53.2 \%)$ \\
\hline \multicolumn{2}{|l|}{ Who cost is shared with $(n=62)$} \\
\hline Father of the child & 27 \\
\hline Other family members & 35 \\
\hline \multicolumn{2}{|l|}{ Responsible for paying for rent } \\
\hline Mother alone & $50(18.9 \%)$ \\
\hline Shares the cost & $19(7.2 \%)$ \\
\hline Do not pay/not applicable & $196(74.0 \%)$ \\
\hline \multicolumn{2}{|l|}{ Who cost is shared with $(n=19)$} \\
\hline Father of the child & 12 \\
\hline Other family members & 7 \\
\hline Non-family member & 0 \\
\hline \multicolumn{2}{|l|}{ Responsible for paying for groceries } \\
\hline Mother alone & $72(27.2 \%)$ \\
\hline Shares the cost & $157(59.2 \%)$ \\
\hline Do not pay/not applicable & $36(13.6 \%)$ \\
\hline \multicolumn{2}{|l|}{ Who cost is shared with $(n=157)$} \\
\hline Father of the child & 61 \\
\hline Other family members & 95 \\
\hline Non-family member & 1 \\
\hline \multicolumn{2}{|l|}{ Responsible for transport costs } \\
\hline Mother alone & $207(78.1 \%)$ \\
\hline Shares the cost & $37(14.0 \%)$ \\
\hline Do not pay/not applicable & $21(7.9 \%)$ \\
\hline \multicolumn{2}{|l|}{ Who cost is shared with $(n=37)$} \\
\hline Father of the child & 33 \\
\hline Other family members & 1 \\
\hline Non-family member & 3 \\
\hline \multicolumn{2}{|l|}{ Expenses for the child } \\
\hline \multicolumn{2}{|l|}{ Responsible for paying for children's clothes } \\
\hline Mother alone & $66(24.9 \%)$ \\
\hline Shares the cost & $181(68.3 \%)$ \\
\hline Do not pay / not applicable & $18(6.8 \%)$ \\
\hline \multicolumn{2}{|l|}{ Who cost is shared with $(n=181)$} \\
\hline Father of the child & 168 \\
\hline Other family members & 10 \\
\hline Non-family member & 2 \\
\hline \multicolumn{2}{|c|}{ Responsible for paying for child's food or milk } \\
\hline Mother alone & $56(21.1 \%)$ \\
\hline Shares the cost & $154(58.1 \%)$ \\
\hline Do not pay / not applicable & $55(20.8 \%)$ \\
\hline \multicolumn{2}{|l|}{ Who cost is shared with $(n=154)$} \\
\hline Father of the child & 140 \\
\hline Other family members & 13 \\
\hline Non-family member & 1 \\
\hline
\end{tabular}

Table 5 (continued)

\begin{tabular}{ll}
\hline Participants' financial responsibilities & All \\
& $\mathbf{n = 2 6 5}(\%)$ \\
\hline Responsible for paying school fees & $72(27.2 \%)$ \\
Mother alone & $32(12.1 \%)$ \\
Shares the cost & $161(60.8 \%)$ \\
Do not pay / not applicable & \\
Who cost is shared with ( $\mathrm{n}=32)$ & 27 \\
Father of the child & 5 \\
Other family members & 0 \\
Non-family member & \\
Responsible for paying childcare & $89(33.6 \%)$ \\
Mother alone & $41(15.5 \%)$ \\
Shares the cost & $135(50.9 \%)$ \\
Do not pay/not applicable & \\
Who cost is shared with $(\mathrm{n}=41)$ & 40 \\
Father of the child & 1 \\
Other family members & 0 \\
Non-family member &
\end{tabular}

less than R1 000 per month, and among mothers reporting themselves HIV positive. Mothers who reported receiving financial support from the child's father were less likely to be food insecure.

\section{Depression risk}

Among all participants, 8.3\% (22/265) were identified at risk of depression using the EPDS score cut off $\geq 13$. To provide estimates of depression risk in the postnatal period we considered depression risk among mothers with children $<12$ months of age $(132 / 265)$. Of these mothers, $6.8 \%$ (9/132) were identified as being at risk of postnatal depression. Among 133 mothers with a child aged between 12 and 35 months, 13 mothers scored high on the EPDS (13/133; 9.8\%). There was no significant difference between depression risk among mothers in the postnatal period compared to mothers with older children $(p=0.38)$. Results were similar using the alternative Whooley Score, where a slightly higher percentage of mothers $(40 / 265 ; 15.1 \%)$ were identified as at risk of depression. Again, prevalence of depression risk was similar among mothers with children under 12 months $(21 / 132 ; 15.9 \%)$ and mothers with older children $(19 / 133 ; 14.3 \%)$.

A small number of participants expressed thoughts of self-harm. Using EPDS, 12 mothers (4.5\%) reported they had thought of harming themselves in the past 7 days, as compared to Whooley where 10 mothers (3.8\%) reported they had thoughts about self-harm in the past 2 weeks. 


\section{Factors associated with high depression risk}

In order to determine the relationship between food insecurity and depression, we dichotomised the food insecurity variable as no or mild food insecurity versus moderate or severe food insecurity.

Using the EPDS score as a continuous variable, Table 6 shows after adjusting for possible risk factors there is a significantly higher risk of postnatal depression among mothers living in households where there is moderate or severe food insecurity. However, receiving financial support from the child's father and working regular hours were associated with a lower average EPDS score. In our study there was no association between risk of depression and HIV status.

\section{Discussion}

Despite the large number of women working informally in SA and throughout the Global South, very little is known about the relationship between informal work, food security and depression among mothers of young

Table 6 Factors associated with depression risk with EPDS score as continuous variable

\begin{tabular}{|c|c|c|c|c|c|c|c|c|c|}
\hline \multirow[t]{2}{*}{$\mathrm{N}=265$} & \multicolumn{3}{|c|}{$\begin{array}{l}\text { Mean post-natal depression } \\
\text { score }\end{array}$} & \multicolumn{3}{|c|}{ Bivariable } & \multicolumn{3}{|c|}{ Multivariable } \\
\hline & $\mathbf{n}$ & Mean & SD & OR & $95 \% \mathrm{Cl}$ & $p$ & OR & $95 \% \mathrm{Cl}$ & $p$ \\
\hline \multicolumn{10}{|l|}{ Mother's age } \\
\hline$<30$ years & 138 & 5.34 & 4.94 & Ref & & & & & \\
\hline $30-47$ & 126 & 5.73 & 4.86 & 1.07 & $(0.8-1.4)$ & 0.58 & na & & na \\
\hline \multicolumn{10}{|l|}{ Mother's education } \\
\hline$<$ Grade 12 & 131 & 6.16 & 5.39 & REF & & & & & \\
\hline$\geq$ Grade 12 & 134 & 4.88 & 4.28 & 0.79 & $(0.6-1.0)$ & 0.07 & 0.85 & $(0.7-1.1)$ & 0.18 \\
\hline \multicolumn{10}{|c|}{ Mother in a relationship with child's father } \\
\hline No & 57 & 6.65 & 4.96 & Ref & & & & & \\
\hline Yes & 208 & 5.20 & 4.84 & 0.78 & $(0.6-1.1)$ & 0.11 & 0.93 & $(0.7-1.3)$ & 0.67 \\
\hline \multicolumn{10}{|c|}{ Father gives money to support the child } \\
\hline No & 84 & 7.30 & 5.09 & Ref & & & & & \\
\hline Yes & 181 & 4.69 & 4.58 & 0.64 & $(0.5-0.83)$ & $<0.001$ & 0.73 & $(0.6-0.9)$ & 0.03 \\
\hline \multicolumn{10}{|c|}{ Mother receives child support grant } \\
\hline No & 57 & 5.84 & 5.01 & Ref & & & & & \\
\hline Yes & 208 & 5.42 & 4.87 & 0.93 & $(0.7-1.30)$ & 0.63 & na & & \\
\hline \multicolumn{10}{|l|}{ Monthly earning } \\
\hline$<R 1000$ & 79 & 6.27 & 5.26 & Ref & & & & & \\
\hline R2000-2999 & 149 & 5.34 & 4.75 & 0.85 & $(0.6-1.1)$ & 0.26 & 0.90 & $(0.8-1.3)$ & 0.93 \\
\hline$\geq R 3000$ & 37 & 4.59 & 4.53 & 0.73 & $(0.5-1.1)$ & 0.13 & 1.03 & $(0.7-1.5)$ & 0.88 \\
\hline \multicolumn{10}{|l|}{ Salary } \\
\hline Not fixed & 164 & 5.52 & 5.03 & Ref & & & & & \\
\hline Fixed & 101 & 5.50 & 4.69 & 0.90 & $0.8-1.3)$ & 0.98 & na & & \\
\hline \multicolumn{10}{|l|}{ Working hours } \\
\hline Irregular & 64 & 6.39 & 5.41 & Ref & & & & & \\
\hline Regular & 201 & 5.23 & 4.70 & 0.82 & $(0.6-1.1)$ & 0.17 & 0.75 & $(0.6-0.9)$ & 0.03 \\
\hline \multicolumn{10}{|l|}{ Stable work } \\
\hline$<4$ years & 207 & 5.57 & 4.72 & Ref & & & & & \\
\hline$\geq 4$ years & 58 & 5.29 & 5.52 & 0.95 & $(0.7-1.3)$ & 0.74 & na & & \\
\hline \multicolumn{10}{|l|}{ Self-reported HIV positive } \\
\hline Negative & 117 & 4.91 & 4.59 & Ref & & & & & \\
\hline Positive & 131 & 6.19 & 5.19 & 1.26 & $(0.9-1.6)$ & 0.08 & 0.97 & $(0.8-1.2)$ & 0.80 \\
\hline No answer/no test & 17 & 4.41 & 3.99 & na & & & & & \\
\hline \multicolumn{10}{|c|}{ Household Food Insecurity Access Scale (HFIAS) } \\
\hline Secure/mild insecure & 150 & 3.67 & 3.93 & Ref & & & & & \\
\hline Moderate/severe insecure & 115 & 7.91 & 5.00 & 2.15 & $(1.7-2.8)$ & $<0.001$ & 2.09 & $(1.6-2.6)$ & $<0.001$ \\
\hline
\end{tabular}


children working in the informal economy. This study sought to address this gap to inform the development of strategies to improve maternal and child health and enable more stable livelihoods for these women.

Our findings show that women in informal work were living in poverty, frequently on very low, unstable incomes despite being responsible for many household and personal expenses. Almost one third of women were earning < R1 000 per month, well below the upper bound poverty line for SA, meaning that this amount is insufficient to supply an individual's basic food and non-food requirements [47]. Types of work, employment conditions and places of work differed among these women, with employed women and domestic workers benefitting from a relatively stable income and work environment compared to self-employed workers, particularly informal market traders. Informal women workers reported high levels of moderate or severe household food insecurity, when compared with the SA average. Most women took very little or no time off work after childbirth, most likely for financial reasons, and this was likely to affect their ability to breastfeed and care for their children. Studies have shown that inability to adequately provide for the households' food needs is a key indicator of poverty, and is a significant source of anxiety and determinant of poor mental health [22, 48]. More multidisciplinary interventions are needed to address these intersecting life challenges of informal working women using a cross-cutting approach [49].

The post-partum period is a vulnerable time for many women, one reason for this is the loss of income at the same time as they have the additional expense of providing for a new baby. Although some women who received the CSG experienced food insecurity, many women reported that the grant money they received for their older children helped support them during their maternity leave. This is supported by other studies, which have further shown that receipt of the CSG can reduce hunger, and improve child nutrition [50]. However, although the SA CSG is the largest cash transfer programme in Africa, reaching over 11 million children, the amount is insufficient to ensure adequate dietary diversity for children or protect low-income families from financial shocks [51]. The CSG is a cornerstone of poverty alleviation in SA but access to the grant remains a challenge, particularly for mothers in extreme poverty. Over $10 \%$ of women in our study did not receive any grant, and more needs to be done to address this [52]. In addition, payments start several weeks after the baby is born. Therefore, extension of the CSG to cover the antenatal period would improve coverage and be very likely to improve mothers' ability to take time off work to breastfeed and care for their new baby.
The depression risk among our population was lower than has been found in several other studies in SA [5, 7, $8]$, and was similar using two different validated screening tools for depression. This relatively low depression risk was found despite women living in contexts of social and economic adversity and food insecurity, that are known to be associated with high rates of depression [15]. Employment is associated with improved selfesteem and being employed is associated with a reduced risk of anxiety and depression [53]. The support that mothers received from their own family, both financial and practical, could also be a factor in protecting women from depression. Another explanation for low rates of depression risk is that informal women workers may have built significant agency and resilience in response to the considerable adversities they have faced in the workplace. The converse may also be true if high levels of resilience enable women to identify and take up opportunities to generate income from informal work. A person displays resilience when they are able to adjust well to significant risk [54]. Although our study did not measure women's sense of agency or resilience, it appears that informal workers are resourceful and empowered women who may have learned to actively buffer their health from life stressors. Very few studies are available that explain resilience among women in SA, let alone women who work in the informal economy who face many risks. More research is needed to understand, demonstrate and explain this resilience, as well as the role of social support, to inform more effective mental health interventions, particularly for marginalised women [54].

Most mothers relied extensively on practical and financial support from their family, including after childbirth and before their return to work. In particular, we found that receiving financial support from a current partner was an important mitigating factor for both food insecurity and depression. This suggests that the intimate partner relationship is central to women's well-being, supporting findings from other studies [5]. However, despite being in a relationship with the father of their child, most women were living with their own family. This is common in SA because of the custom for men to pay a substantial bride price (known as "Lebola") before marriage. As a result, while the child's father contributed to the child's expenses, this support did not extend to cover household running costs or women's personal expenses, leaving women to carry the burden of providing a home for themselves and their child. Thus, these women experienced the "double-burden" of income earning work and managing childcare and household responsibilities. While this is common among women in many settings, it is likely that women working in the informal sector, with few labour protections, are particularly 
affected [30]. In addition, childcare is often considered to be the mother's decision and her sole responsibility [55]. Encouraging positive gender and social attitudes towards childcare in the community and in the workplace through increased awareness of the importance of early nutrition and nurturing care, could strengthen the role of society, including social and public services, in supporting and protecting childcare. Clinic staff, community health workers, and local organisations could support awareness campaigns in the community to improve awareness of nurturing care.

Lack of service support and policy frameworks for women working in the informal economy means public authorities, employers and decision-makers currently have no responsibilities to engage with these issues. However, where there are informal workers working in formal work settings, for example undertaking casual cleaning or administrative work, labour regulations should be enforced. While some organizations have been active in advocating for women's rights and livelihoods [56], it will be important to further mobilise worker and women's rights organisations and key decision-makers to acknowledge or advocate for the rights of informal working women and their children. This includes advocacy for maternity leave agreements, by-laws which support working pregnant women and mothers, the allocation of safer spaces for childcare facilities and the safe-guarding of trading spaces when pregnant women and mothers are away due to childbirth, breastfeeding or caring for their children. Providing social protection to informal working women during the perinatal period, such as through a pregnancy grant, extended CSG or community saving schemes, could safeguard women's employment during late pregnancy or the early postnatal period, thereby stabilizing incomes and supporting women's and children's health, in particular by delaying the time to return to work after childbirth.

The health system also has an important role to play in addressing the interaction between food insecurity, depression, poverty and informal work. First, health services, including mental health care, should be free, available and accessible to informal working mothers and their children. This would require reorienting the health system so PHC opening hours and available services are organised to meet the needs of women working in the informal economy. For example, women start their trading or domestic work well before health facilities commonly open. As a result, women lose income if they attend a clinic, especially if it is a distance away. To enable more responsive, people-centred care, a solution could be to extend the role of community health workers (CHWs) from visiting homes to include visiting public spaces, which are also women's workspaces.
Second, in addition to clinical services, women need the capacity, including personal and social efficacy, to sustain their livelihoods while ensuring infants are appropriately fed and cared for. Health providers have a critical role to play in providing life-skills training and mentoring support for women to enable them to problem-solve, plan, and make decisions about their lives and caring for their child. In addition, to support early nutrition and nurturing care, infant feeding and responsive childcare training would enable mothers and caregivers to make and implement optimal, evidence-based caregiving choices for their infants and young children.

Lastly, service support and health workforce strengthening are critical. For example, health care providers must have the capacity to confidently and competently provide services to women working in the informal sector and their children, and be supported by systems that invest in their professional development and well-being.

\section{Strengths and limitations of the study}

One strength of this study was the use of two different locally validated tools to assess depression risk, which allowed for triangulation of the findings and strengthened the results. Field workers were trained and supervised by a professional psychologist to ensure consistency and appropriate use of the tools.

However, some limitations must be acknowledged. Although mothers' risk of depression was identified using screening tools, we did not conduct a full depression assessment to confirm the depression diagnosis. In addition, although the tools used to assess depression and food insecurity had been validated in SA and were translated into isiZulu, it is possible that cultural and language differences may have led to different interpretations of the questions. All participants were aware that referral mechanisms were in place, and participants may have believed that over-reporting indicators of poverty and depression would give them access to additional support. However, we provided a link to referral services and support that is available to all South Africans, including emergency food supplementation and referral to the South African Social Security agency (SASSA). Women who had been informal workers for $<6$ months were excluded, so that data from this group, who may have become informal workers as a result of having a baby, were not included.

Although we have data about the proportion of fathers supporting the mother at the time of delivery, the survey did not probe for actual details of expenditure. A form of graded categorisation of contribution amount may have allowed for more analysis of the associations of support with the other outcomes of interest. However, we 
recognised it was a balance between obtaining meaningful data and participants not finding the questions too intrusive.

\section{Conclusion}

Our study provides unique and important insights into the association between food insecurity, depression, poverty and informal work among women in Durban, SA. The health and livelihoods of women working in the informal economy, and the health and well-being of their infants and young children are compromised by a vicious cycle of vulnerability. This presents a major public health concern, particularly as the high rate of food insecurity greatly increases the risk for poor maternal health and child health and development outcomes [5, 22]. Further research is needed to improve our understanding of these interactions, particularly the role of social support and resilience as a protective factor, and to understand how these interactions compare with women in formal work.

\section{Supplementary Information}

The online version contains supplementary material available at https://doi. org/10.1186/s12905-020-01147-7.

Additional file 1. Survey questionnaire.

\section{Abbreviations}

CHWs: Community Health Workers; CSG: Child Support Grant; EPDS: Edinburgh Postnatal Depression Score; HFIAS: Household Food Insecurity Access Scale; KZN: KwaZulu-Natal; PHC: Primary Health Care; SA: South Africa; UIF: Unemployment Insurance Fund.

\section{Acknowledgements}

The authors would like to thank the KZN Department of Health and staff in the healthcare facilities for their support in conducting the project in the study sites. In addition, the authors would like to thank the participants for their invaluable time and contribution to the study.

\section{Authors' contributions}

$\mathrm{CH}, \mathrm{LH}, \mathrm{SL}$ and NR conceptualized the study. SL supervised the data collection process and CC oversaw the analysis of the data. $\mathrm{CH}, \mathrm{LH}, \mathrm{RH}$ and $\mathrm{CC}$ interpreted the results. $\mathrm{CH}, \mathrm{LH}$ and $\mathrm{RH}$ wrote the first drafts. All the authors reviewed and commented on the manuscript throughout the writing process. All authors read and approved the final manuscript.

\section{Funding}

Funding for the study was provided by the World Health Organization. The views expressed in the manuscript do not necessarily represent the policies or recommendations of the World Health Organization. The funders did not participate or play a role in the design of the study, data collection, data analysis or reporting of the results.

\section{Availability of data and materials}

The data or material used in the study is available from the corresponding author upon reasonable request.

\section{Ethics approval and consent to participate}

Ethical approval for the study were received from the University of KwaZuluNatal Humanities and Social Sciences Research Ethics Committee (HSSREC) (HSS/0319/018), KZN Department of Health (HRKM235/18) and the World Health Organization Ethics Review Committee (ERC 0003101). All the participants signed a consent form prior to participating in the study. To maintain anonymity, codes were used for each participant based on the study site.

\section{Consent for publication}

Not applicable.

\section{Competing interests}

The authors declare that they have no competing interests.

\section{Author details}

${ }^{1}$ Centre for Rural Health, George Campbell Building, Howard College Campus, University of KwaZulu-Natal, Durban, South Africa. ${ }^{2}$ RHEdit, Geneva, Switzerland. ${ }^{3}$ Department of Maternal, Newborn, Child and Adolescent Health World Health Organization, Geneva, Switzerland.

Received: 25 February 2020 Accepted: 11 December 2020 Published online: 02 January 2021

\section{References}

1. Gouda HN, Charlson F, Sorsdahl K, Ahmadzada S, Ferrari AJ, Erskine H, Leung J, Santamauro D, Lund C, Aminde LN, et al. Burden of noncommunicable diseases in sub-Saharan Africa, 1990-2017: results from the Global Burden of Disease Study 2017. Lancet Glob Health. 2019;7(10):e1375-87.

2. Tomlinson M, Swartz L, Kruger LM, Gureje O. Manifestations of affective disturbance in sub-Saharan Africa: key themes. J Affect Disord. 2007:102(1-3):191-8.

3. Hartley M, Tomlinson M, Greco E, Comulada WS, Stewart J, le Roux I, Mbewu N, Rotheram-Borus MJ. Depressed mood in pregnancy: prevalence and correlates in two Cape Town peri-urban settlements. Reprod Health. 2011:8:9.

4. Parsons CE, Young KS, Rochat TJ, Kringelbach ML, Stein A. Postnatal depression and its effects on child development: a review of evidence from low- and middle-income countries. Br Med Bull. 2012;101:57-79.

5. Heyningen TV, Myer L, Onah M, Tomlinson M, Field S, Honikman S. Antenatal depression and adversity in urban South Africa. J Affect Disord. 2016:203:121-9.

6. Marsay C, Manderson L, Subramaney U. Validation of the Whooley questions for antenatal depression and anxiety among low-income women in urban South Africa. S Afr J Psychiatr. 2017:23:1013.

7. Rochat TJ, Tomlinson M, Barnighausen T, Newell ML, Stein A. The prevalence and clinical presentation of antenatal depression in rural South Africa. J Affect Disord. 2011;135(1-3):362-73.

8. Stellenberg EL, Abrahams JM. Prevalence of and factors influencing postnatal depression in a rural community in South Africa. Afr J Prim Health Care Fam Med. 2015;7(1):874.

9. Dewing S, Tomlinson M, le Roux IM, Chopra M, Tsai AC. Food insecurity and its association with co-occurring postnatal depression, hazardous drinking, and suicidality among women in peri-urban South Africa. J Affect Disord. 2013;150(2):460-5.

10. Rotheram-Fuller EJ, Tomlinson M, Scheffler A, Weichle TW, Hayati Rezvan P, Comulada WS, Rotheram-Borus MJ. Maternal patterns of antenatal and postnatal depressed mood and the impact on child health at 3-years postpartum. J Consult Clin Psychol. 2018;86(3):218-30.

11. Rodriguez VJ, Matseke G, Cook R, Bellinger S, Weiss SM, Alcaide ML, Peltzer K, Patton D, Lopez M, Jones DL. Infant development and pre- and post-partum depression in Rural South African HIV-infected women. AIDS Behav. 2018;22(6):1766-74.

12. Nglazi MD, Joubert JD, Stein DJ, Lund C, Wiysonge CS, Vos T, Pillay-van Wyk V, Roomaney RA, Muhwava LS, Bradshaw D. Epidemiology of major depressive disorder in South Africa (1997-2015): a systematic review protocol. BMJ Open. 2016;6(7):e011749.

13. van Heyningen T, Honikman S, Myer L, Onah MN, Field S, Tomlinson M. Prevalence and predictors of anxiety disorders amongst low-income pregnant women in urban South Africa: a cross-sectional study. Arch Womens Ment Health. 2017;20(6):765-75.

14. Hamad R, Fernald LC, Karlan DS, Zinman J. Social and economic correlates of depressive symptoms and perceived stress in South African adults. J Epidemiol Community Health. 2008;62(6):538-44. 
15. Abrahams Z, Lund C, Field S, Honikman S. Factors associated with household food insecurity and depression in pregnant South African women from a low socio-economic setting: a cross-sectional study. Soc Psych Psychiatr Epidemiol. 2018;53(4):363-72.

16. Kathree T, Selohilwe OM, Bhana A, Petersen I. Perceptions of postnatal depression and health care needs in a South African sample: the "mental" in maternal health care. BMC Womens Health. 2014;14:140.

17. Tsai AC, Tomlinson M, Comulada WS, Rotheram-Borus MJ. Intimate partner violence and depression symptom severity among South African women during pregnancy and postpartum: population-based prospective cohort study. PLoS Med. 2016;13(1):e1001943.

18. Tsai AC, Hung KJ, Weiser SD. Is food insecurity associated with HIV risk? Cross-sectional evidence from sexually active women in Brazil. PLoS Med. 2012;9(4):e1001203.

19. Cooper PJ, Tomlinson M, Swartz L, Woolgar M, Murray L, Molteno C. Postpartum depression and the mother-infant relationship in a South African peri-urban settlement. Br J Psych. 1999;175:554-8.

20. Anderson SA. Core indicators of nutritional state for difficult-to-sample populations. J Nutr (USA). 1990;120(Suppl 11):1559-600.

21. Food Agriculture Organization. Rome declaration on world food security and world food summit plan of action: world food summit 13-17 November 1996, Rome, Italy: FAO; 1996.

22. Tsai AC, Bangsberg DR, Frongillo EA, Hunt PW, Muzoora C, Martin JN, Weiser SD. Food insecurity, depression and the modifying role of social support among people living with HIV/AIDS in rural Uganda. Soc Sci Med (1982). 2012;74(12):2012-9.

23. Melchior M, Caspi A, Howard LM, Ambler AP, Bolton H, Mountain N, Moffitt TE. Mental health context of food insecurity: a representative cohort of families with young children. Pediatrics. 2009;124(4):e564-72.

24. Melchior M, Chastang JF, Falissard B, Galera C, Tremblay RE, Cote SM, Boivin M. Food insecurity and children's mental health: a prospective birth cohort study. PLOS ONE. 2012;7(12):e52615.

25. Schmeer KK, Piperata BA. Household food insecurity and child health. Matern Child Nutr. 2017;13(2):e12301.

26. Statistics South Africa. Poverty trends in South Africa: An examination of absolute poverty between 2006 and 2015. Pretoria: Statistics South Africa; 2017.

27. Horwood C, Haskins L, Alfers L, Masango-Muzindutsi Z, Dobson R, Rollins N. A descriptive study to explore working conditions and childcare practices among informal women workers in KwaZulu-Natal, South Africa: identifying opportunities to support childcare for mothers in informal work. BMC Pediatr. 2019;19(1):382.

28. International Labour Organisation. Decent work and the transition to formalisation: recent trends, policy debates and good practices. In: Geneva: ILO Geneva, Switzerland; 2008

29. Statistics South Africa. Quarterly labour force survey: quarter 1 2019. In: Edited by Africa SS. Pretoria: Statistics South Africa; 2019.

30. Alfers L. WIEGO child care initiative literature review. In: Literature review (Manchester, WIEGO). WIEGO; 2015.

31. Santana VS, Loomis D, Newman B, Harlow SD. Informal jobs: another occupational hazard for women's mental health? Int J Epidemiol. 1997;26(6):1236-42.

32. Bhan G, Surie A, Horwood C, Dobson R, Alfers L, Portela A, Rollins N. Informal work and maternal and child health: a blind spot in public health and research. Bull World Health Organ. 2020;98(3):219-21.

33. SA Department of Health SSA. South African Medical Research Council, ICF: South Africa demographic and Health Survey: Key indicators. Pretoria: SA National Department of Health; 2016.

34. South African Population Census. 2011. Indicators derived from the full population Census. https://wazimap.co.za/profiles/province-KZN-kwazu lu-natal/.

35. Child support grant. https://www.gov.za/services/child-care-social-benef its/child-support-grant.

36. SA Department of Health: South African Demographic Health Survey Report. Pretoria: SA Department of Health; 2016.

37. Woldesenbet SA, Kufa T, Lombard C, Manda S, Ayalew K, Cheyip M, Puren A. The 2017 national antenatal sentinel HIV \& syphilis survey, South Africa. Pretoria, South Africa: National Department of Health; 2019.

38. Tsai AC, Scott JA, Hung KJ, Zhu JQ, Matthews LT, Psaros C, Tomlinson M. Reliability and validity of instruments for assessing perinatal depression in African settings: systematic review and meta-analysis. PLoS ONE. 2013;8(12):e82521.

39. Rochat TJ, Tomlinson M, Newell ML, Stein A. Detection of antenatal depression in rural HIV-affected populations with short and ultrashort versions of the Edinburgh Postnatal Depression Scale (EPDS). Arch Womens Ment Health. 2013;16(5):401-10

40. Lawrie TA, Hofmeyr GJ, de Jager M, Berk M. Validation of the Edinburgh Postnatal Depression Scale on a cohort of South African women. S Afr Med J. 1998;88(10):1340-4.

41. Cox JL, Chapman G, Murray D, Jones P. Validation of the Edinburgh Postnatal Depression Scale (EPDS) in non-postnatal women. J Affect Disord. 1996;39(3):185-9.

42. Chibanda D, Mangezi W, Tshimanga M, Woelk G, Rusakaniko P, StranixChibanda L, Midzi S, Maldonado Y, Shetty AK. Validation of the Edinburgh Postnatal Depression Scale among women in a high HIV prevalence area in urban Zimbabwe. Arch Womens Ment Health. 2010;13(3):201-6.

43. Honikman S, van Heyningen T, Field S, Baron E, Tomlinson M. Stepped care for maternal mental health: a case study of the perinatal mental health project in South Africa. PLoS Med. 2012;9(5):e1001222.

44. Swindale A, Bilinsky P. Development of a universally applicable household food insecurity measurement tool: process, current status, and outstanding issues. J Nutr. 2006;136(5):1449S-1452S.

45. Hussein FM, Ahmed AY, Muhammed OS. Household food insecurity access scale and dietary diversity score as a proxy indicator of nutritional status among people living with HIV/AIDS, Bahir Dar, Ethiopia, 2017. PLoS ONE. 2018;13(6):e0199511.

46. Coates J, Swindale A, Bilinsky P. Household Food Insecurity Access Scale (HFIAS) for measurement of food access: indicator guide. Washington, DC: Food and Nutrition Technical Assistance Project, Academy for Educational Development 2007, 34.

47. Statistics South Africa. National Poverty Lines 2019. Pretoria: statistics South Africa; 2019.

48. Sorsdahl K, Slopen N, Siefert K, Seedat S, Stein DJ, Williams DR. Household food insufficiency and mental health in South Africa. J Epidemiol Community Health. 2011;65(5):426-31.

49. Laurenzi C, Field S, Honikman S. Food insecurity, maternal mental health, and domestic violence: a call for a syndemic approach to research and interventions. Mater Child Health J. 2020;24(4):401-4.

50. Zembe-Mkabile W, Ramokolo V, Sanders D, Jackson D, Doherty T. The dynamic relationship between cash transfers and child health: can the child support grant in South Africa make a difference to child nutrition? Public Health Nutr. 2016;19(2):356-62

51. Zembe-Mkabile W, Surender R, Sanders D, Jackson D, Doherty T. The experience of cash transfers in alleviating childhood poverty in South Africa: mothers' experiences of the Child Support Grant. Glob Public Health. 2015;10(7):834-51.

52. Gibbs A, Washington L, Jama Shai N, Sikweyiya Y, Willan S. Systematically excluded: Young women's experiences of accessing child support grants in South Africa. Global Public Health. 2018;13(12):1820-30.

53. Lund C, Brooke-Sumner C, Baingana F, Baron EC, Breuer E, Chandra P, Haushofer J, Herrman H, Jordans M, Kieling C, et al. Social determinants of mental disorders and the Sustainable Development Goals: a systematic review of reviews. Lancet Psych. 2018;5(4):357-69.

54. Jefferis TC, Theron LC. Explanations of resilience in women and girls: how applicable to black South African girls. In: Women's studies international forum: 2018: Elsevier; 2018. p. 195-211.

55. Alfers L. Our children don't get the attention they deserve: a synthesis of research findings on women informal workers and child care from six membership based organizations. Cambridge, MA: Women in Informal Employment: Globalizing and Organizing; 2016.

56. Women in Informal economy: globalising and organising. https://www wiego.org/.

\section{Publisher's Note}

Springer Nature remains neutral with regard to jurisdictional claims in published maps and institutional affiliations. 